\title{
Influence of age at nutritional restriction on growth and sexual development of gilts
}

\author{
A Prunier
}

INRA, Station de Recherches Porcines, 35590 Saint-Gilles, France

(Received 5 February 1991; accepted 28 August 1991)

\begin{abstract}
Summary - Large White females were fed on a plane of nutrition close to ad libitum during the entire experimental period (CTRL group, $n=48$ ) or restricted during a limited period of their growth (RP1 group: $28-62 \mathrm{~kg}$. RP2 group: $64-96 \mathrm{~kg}$, RP3 group: $97-131 \mathrm{~kg}, n=48 /$ group). Blood samples were taken before 200 and 230 days of age in order to detect cyclic gilts by assaying their progesterone levels. Animals were slaughtered at $\approx 260 \mathrm{~d}$ of age and their genital tracts were examined. Overall feed intake, feed conversion ratio and daily gain were significantly lower in restricted than in CTRL gilts (average daily gain: $678,680,668$ and $741 \mathrm{~g} /$ day respectively in RP1, RP2, RP3 and CTRL groups, $P<0.05$ ). At slaughter, animals from the 3 restricted groups had similar live weights but were lighter (152 vs $164 \mathrm{~kg}$ live weight, $P<0.05$ ) and leaner than CTRL (fat thickness: 29.5, 30.5, 28.0 and $34.1 \mathrm{~mm}$ respectively, in RP1, RP2, RP3 and CTRL groups). Respectively, 9, 43 and $76 \%$ of the gilts were puberal at 200,230 and 260 days of age. The percentage of cyclic females was not influenced by treatment at 200 and 260 days of age while it was higher in CTRL $(50 \%)$ and RP1 $(56 \%)$ groups than in RP2 $(35 \%)$ and RP3 $(29 \%)$ groups at 230 days of age $(P<0.05)$. At 260 days of age, ovarian and genital tract weights were not influenced by treatment either in prepuberal or in cyclic gilts. The number of corpora lutea in cyclic females was also similar in the 4 treatment groups. This experiment confirms that feed restriction can delay the attainment of puberty and shows that its effect depends on the time of application.
\end{abstract}

gilt / puberty / nutritional restriction / growth / progesterone

Résumé - Influence du moment d'application d'une restriction alimentaire sur la croissance et le développement sexuel des truies. Des femelles de race Large White étaient nourries selon un plan d'alimentation proche du niveau ad libitum pendant toute la durée de l'expérience (groupe CTRL, $n=48$ ) ou rationnées de près de $30 \%$ pendant une période limitée de leur croissance (groupe RP1: 28-62 kg, groupe RP2 : 64-96 kg, groupe RP3 : 97-131 kg, $\mathrm{n}=48 /$ groupe). Des prises de sang étaient effectuées juste avant 200 et $230 j$ d'âge afin de détecter les fermelles cycliques par dosage de la progestérone. Toutes les femelles étaient abattues aux alentours de $260 \mathrm{j}$ d'âge et les tractus génitaux étaient prélevés et disséqués. Sur l'ensemble de l'expérience, la consommation d'aliment, lindice de consommation et le gain de poids quotidien étaient plus faibles chez les femelles rationnées que chez celles du groupe témoin (gain moyen quotidien: 678,680 , 668 et $741 \mathrm{~g} / \mathrm{j}$ respectivement pour les groupes RP1, RP2, RP3 et CTRL; $\mathrm{P}<0,05$ ). A l'abattage, les animaux des 3 groupes restreints avaient un poids vif similaire mais ils étaient plus légers (152 vs $164 \mathrm{~kg}, \mathrm{P}<0,05$ ) et plus maigres que les témoins (épaisseur de lard: 29,5;30,5;28,0 et 34,1 mm respectivement pour les groupes $R P 1, R P 2, R P 3$ et $C T R L ; P<0,05$ ). Respectivement 9,43 et $76 \%$ 
des femelles étaient pubères à 200, 230 et $260 j$ d'âge. Ce pourcentage de truies cycliques était indépendant du traitement à 200 et $260 j$ d'âge alors qu'à $230 \mathrm{j}$, il était plus élevé dans les groupes CTRL. (50\%) et RP1 (56\%) que dans les groupes RP2 (35\%) et RP3 (29\%), (P< 0,05). A $260 j$ d'âge, le poids des ovaires et du tractus génital était indépendant du traitement chez les femelles prépubères et cycliques. Le nombre de corps jaunes des femelles cycliques était également indépendant du traitement. Cette expérience confirme qu'une restriction alimentaire peut induire un retard de puberté et montre que l'effet produit dépend du moment auquel elle intervient.

truie / puberté / rationnement alimentaire / croissance / progestérone

\section{INTRODUCTION}

Nutrition during the rearing period and the consequent alterations of the live weight and body composition may influence the sexual development of the gilt (Etienne et al, 1983; Den Hartog and Noordewier, 1984; Kirkwood and Aherne, 1985; Prunier et al, 1987). However, it is not clear whether the influence of feed restriction is a direct effect on the attainment of puberty or is mediated by its effects on live weight and/or body composition. On the one hand, most experiments with moderate feed restriction show alterations in live weight and body composition without concomitant modification of age at puberty (Aherne et al, 1976; Etienne et al, 1983; Den Hartog and Noordewier, 1984). On the other, some authors have shown negative relationships between average daily gain or backfat thickness before puberty and age at puberty (Den Hartog and Noordewier, 1984; King, 1989). Since sexual maturation of the gilt occurs in 4 phases (Camous et al, 1985): a perinatal phase, an infancy period (2nd month of age), a phase of initiation of sexual development (3rd to 5th months of age) and a waiting period (6th month of age to puberty), undernutrition during one or many of these periods may have specific effects. This point has been poorly investigated. Piglets whose milk intake was reduced during the first 8 weeks of life are slightly lighter at 140 days of age than non-restricted piglets (5.4 kg live weight difference) but reach puberty at the same age (Nelson and Robison, 1976) while undernutrition between 28 and $61 \mathrm{~kg}$ live weight delays age at first cestrus (Etienne et al, 1983). The aim of the present study was to determine if undernutrition during one of the periods of sexual development has specific effects on the attainment of puberty.

\section{MATERIALS AND METHODS}

\section{Animals}

Sixty-four Large White gilts from 20 groups of 3 or 4 littermates were allocated to 4 treatment groups on a within-litter basis. Three replicates of this design were carried out with females born in November and December 1986, June 1987 and February 1988. Age and live weight at allotment were respectively $77 \pm 5$ days and $28 \pm 3$ $\mathrm{kg}$ (mean $\pm \mathrm{SD}$ ).

All the animals received the same diet containing 12.9 $\mathrm{MJ}$ of digestible energy per $\mathrm{kg}$, $17.3 \%$ of protein and $0.83 \%$ of lysine. Up to slaughter, the control females (CTRL) were fed according to a scale close to ad libitum and ranging between $1.1 \mathrm{~kg} /$ day at 20 to $25 \mathrm{~kg}$ live weight and $3.2 \mathrm{~kg} /$ day from $105 \mathrm{~kg}$ of live weight until slaughter. Restricted gilts received the same diet as the CTRL females until they were offered $70 \%$ of the CTRL diet during a limited 
period occurring between 28 and $62 \mathrm{~kg}$ live weight (period P1) for the RP1 group, 64 and 96 $\mathrm{kg}$ (period P2) for the RP2 group and, 97 and $131 \mathrm{~kg}$ (period P3) for the RP3 group. For the RP2 and RP3 groups, food supply was progressively reduced on 5 days. After the period of restriction, restricted gilts were pair-fed with the CTRL ones. Moments of feed restriction were based on live weight in order to be sure that restricted animals would attain the same live weight at the end of the last period of restriction. All the females were weighed at weekly intervals and on the day of slaughter. They were housed in groups of 4 under natural daylight. Feed refusals were collected daily, pooled and measured weekly and feed intake was then calculated at weekly intervals.

Two blood samples were collected by venipuncture at a 9-13 day interval before 200 days of age and 2 others before 230 days. Plasma progesterone was assayed on these samples according to the method described by Terqui and Thimonier (1974). When at least 1 of the 2 samples collected before 200 days of age contained > $2 \mathrm{ng}$ progesterone/ml, the female was considered cyclic and prepuberal otherwise. The same method was applied at 230 days of age.

Females of the same litter were slaughtered the same day at $261 \pm 2$ days of age. The genital tracts were removed and trimmed of their ligaments. The weights of the ovaries and of the genital tract (uterine horns plus cervix plus vagina) were recorded. Ovaries were dissected, the presence of corpora lutea was depicted and their number was determined.

Backfat thickness was measured at slaughter in 3 sites (on the mid line at the level of the gluteus medius muscle, $8 \mathrm{~cm}$ laterally at the level of the 3rd-4th lumbar vertebrae and $6 \mathrm{~cm}$ laterally at the level of the 3rd-4th ribs) with a Fat-OMeat'er device as described by Desmoulin et al (1984). The mean of the 3 sites was calculated for statistical analysis.

\section{Statistical analysis}

Since animals were penned in groups, means of feed intake and feed conversion ratio were calculated for each pen and submitted to statistical analysis. The effects of the treatments on the percentage of cyclic females at 200, 230 and
260 days of age were assessed with the $\chi^{2}$ test. The other data were analyzed by analysis of variance using the GLM procedure of the Statistical Analysis Systems Institute (1985). The model for growth performance included replicate and treatment as main effects, the litter within replicate effect and the interaction between replicate and treatment. Characteristics of the genital tracts were analyzed separately for prepuberal and cyclic gilts. The model included replicate, treatment and the interaction between these offects.

\section{RESULTS}

\section{Feed intake and growth performance}

Age of the females at the end of each period of feed restriction is given in table $I$. Live weight at slaughter was similar in the 3 restricted groups but significantly lower than in the CTRL group.

During the period of restriction, feed intake compared to the CTRL group was reduced between 28.3 and $31.9 \%$ and average daily gain was decreased between $33.1-34.2 \%$ (table II). During this period, the ratio of feed conversion in the restricted group was non-significantly increased. Thereafter, growth rate and ratio of feed conversion were always improved in the restricted groups even though the difference with the CTRL group was seldom significant (table II). Feed restriction induced an overall significant decrease of 12.5 to $14.0 \%$ for feed intake $(P<0.05)$, and 8.2 to $9.8 \%$ for growth rate $(P<0.05)$. Ratio of feed conversion was improved between 3.7 and $6.3 \%$ in the 3 restricted groups but this effect was significant only in the RP1 and RP2 groups.

Finally, feed restriction resulted in lower backfat thickness at slaughter (table II). This effect was more pronounced in the group with the latest period of restriction. 


\section{Sexual development}

Respectively, 9, 43 and $76 \%$ of the gilts were puberal at 200,230 and 260 days of age. Treatment had no effect on the attainment of puberty at 200 and 260 days of age while the percentage of cyclic gilts was significantly lower in the RP2 and RP3 groups than in the CTRL and RP1 groups at 230 days of age (fig 1).

Weights of the ovaries and of the genital tract were significantly lower in prepuberal (ovaries: $7.1 \pm 0.2 \mathrm{~g}$, genital tract: $268 \pm 20 \mathrm{~g}$, mean \pm standard error of the mean, $n=45$ ) than in cyclic gilts (ovaries: $13.6 \pm 0,4 \mathrm{~g}$, genital tract: $757 \pm 15 \mathrm{~g}, n=$ $145, P<0.01)$. However, within prepuberal and cyclic groups of females they did not differ between treatments. Similarly, the number of corpora lutea $(16.1 \pm 0.2)$ in cyclic females was not influenced by the feed restriction.

\section{DISCUSSION}

Undernutrition during a limited period of growth without the possibility of compensate for it thereafter induced an overall reduction of live weight and fat tissue development at a fixed age and an improvement of feed efficiency. The effect on fat tissue was more pronounced when feed restriction occurred later in development while the effect on feed efficiency was higher when feed restriction occurred earlier. The influence of the time of restriction on fat tissue development was expected since the rate of fat deposition increases during growth (Metz et al, 1980; Den Hartog and Noordewier, 1984). The effect
Table I. Influence of treatments on age at the end of the 3 periods of feed restriction and live weight at slaughter (mean \pm SEM).

$$
\text { CTRL } \quad R P 1 \quad \begin{gathered}
\text { Treatment } \\
R P 2
\end{gathered} \quad R P 3
$$

\section{Age (days)}

End of P1 $125 \pm 1^{\mathrm{a}} \quad 149 \pm 1^{\mathrm{b}} \quad 127 \pm 1^{\mathrm{a}} \quad 127 \pm 1^{\mathrm{a}}$

End of P2 $168 \pm 1^{\mathrm{a}} \quad 187 \pm 1^{\mathrm{b}} \quad 186 \pm 1^{\mathrm{b}} 168 \pm 1^{\mathrm{a}}$

End of P3 $213 \pm 1^{\mathrm{a}} \quad 230 \pm 1^{\mathrm{b}} \quad 232 \pm 1^{\mathrm{b}} 232 \pm 1^{\mathrm{b}}$

\section{Live weight $(\mathrm{kg})$}

Slaughter $\quad 164 \pm 2^{\mathrm{a}} \quad 153 \pm 2^{\mathrm{b}} \quad 153 \pm 2^{\mathrm{b}} \quad 151 \pm 2^{\mathrm{b}}$

a,b Means with different superscripts in the same line differ significantly $(P<0.05)$.

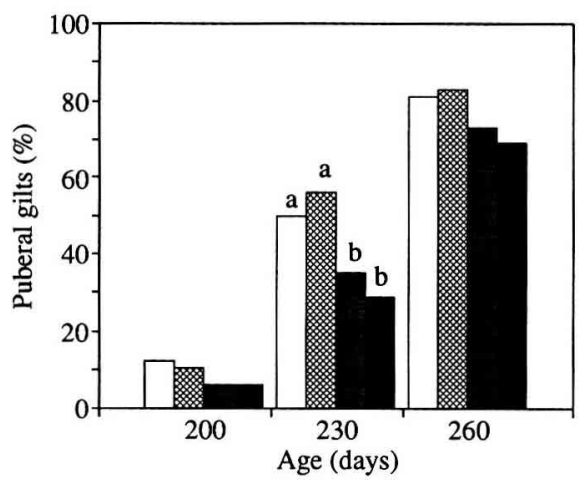

Fig 1. Effects of treatment on the attainment of puberty in gilts ( $\square$ CTRL, RP1, RP3 and RP4). At 230 days of age, percentages with different superscripts differ significantly $(P<$ 0.05). 
Table II. Influence of treatments on feed intake, growth performance, feed conversion ratio and backfat thickness (mean \pm SEM).

\begin{tabular}{|c|c|c|c|c|c|}
\hline Treatment & CTRL & $R P 1$ & RP2 & $R P 3$ & $\begin{array}{l}\text { Overall statistical } \\
\text { significance }\end{array}$ \\
\hline \multicolumn{6}{|c|}{ Feed intake (kg/day) } \\
\hline During P1 & $2.01 \pm 0.05^{a}$ & $1.41 \pm 0.02^{b}$ & $2.05 \pm 0.05^{a}$ & $2.04 \pm 0.02^{a}$ & $\star \star \star *$ \\
\hline During P2 & $2.88 \pm 0.04^{a}$ & $2.82 \pm 0.01^{a}$ & $1.96 \pm 0.03^{b}$ & $2.86 \pm 0.01^{a}$ & $m * *$ \\
\hline During P3 & $3.15 \pm 0.01^{\mathrm{ab}}$ & $3.17 \pm 0.01^{a}$ & $3.12 \pm 0.01^{a}$ & $2.26 \pm 0.01^{c}$ & $* * *$ \\
\hline During P4 & $3.20 \pm 0.06$ & $3.20 \pm 0.12$ & $3.12 \pm 0.09$ & $3.18 \pm 0.15$ & NS \\
\hline \multicolumn{6}{|c|}{ Daily gain (kg/day) } \\
\hline During $P 1$ & $717 \pm 12^{a}$ & $477 \pm 10^{b}$ & $724 \pm 15^{a}$ & $715 \pm 9^{a}$ & $* * *$ \\
\hline During P2 & $836 \pm 15^{b}$ & $901 \pm 13^{a}$ & $550 \pm 13^{c}$ & $727 \pm 13^{b}$ & $* *$ \\
\hline During P3 & $785 \pm 15^{a}$ & $834 \pm 15^{a}$ & $808 \pm 14^{a}$ & $525 \pm 14^{b}$ & $\star * \star$ \\
\hline During P4 & $646 \pm 19$ & $659 \pm 24$ & $655 \pm 19$ & $679 \pm 22$ & NS \\
\hline \multicolumn{6}{|c|}{ Feed conversion ratio (feed intake/daily gain) } \\
\hline During P1 & $2.81 \pm 0.03$ & $2.96 \pm 0.06$ & $2.84 \pm 0.06$ & $2.85 \pm 0.03$ & NS \\
\hline During P2 & $3.46 \pm 0.04^{a}$ & $3.13 \pm 0.04^{b}$ & $3.57 \pm 0.08^{a}$ & $3.46 \pm 0.05^{a}$ & $* * *$ \\
\hline During P3 & $4.05 \pm 0.03^{\mathrm{ab}}$ & $3.82 \pm 0.09^{b}$ & $3.85 \pm 0.08^{b}$ & $4.32 \pm 0.08^{a}$ & $* * *$ \\
\hline During P4 & $4.94 \pm 0.09 a$ & $4.80 \pm 0.20^{a}$ & $4.73 \pm 0.19 \mathrm{ab}$ & $4.34 \pm 0.19^{b}$ & * \\
\hline \multicolumn{6}{|c|}{ Fat depth $(\mathrm{mm})$} \\
\hline & $34.1 \pm 0.8^{a}$ & $29.5 \pm 0.6^{b c}$ & $30.5 \pm 0.6^{b}$ & $28.0 \pm 0.6^{c}$ & $\star \star \star$ \\
\hline
\end{tabular}

NS $P>0.1,{ }^{*} P<0.05,{ }^{* * *} P<0.01{ }^{\text {a,b,c }}$ Means with different superscripts in the same line differ significantly $(P<$ 0.05).

of the time of undernutrition on feed efficiency can also be explained. During the period of restriction, feed efficiency was non-significantly reduced. This result is in agreement with those of Agde et al (1978) and Kirchgessner et al (1979) showing that, when feed intake is limited to $70 \%$ or less of the ad libitum intake, feed efficiency decreases, the fraction of energy devoted to growth being reduced. After the period of restriction, growth rate and feed efficiency were improved. This observation of compensatory growth is in agreement with Adge et al (1978) and Kirchgessner et al
(1979). Thus, it seems normal that the overall influence of restriction on feed efficiency, measured on animals at the same age but with different live weight at the end-point depends on the time at which it is imposed and that it is all the more positive since it occurs earlier in growth.

In our study, puberty was delayed when undernutrition occurred during the waiting phase, while there was no effect when it occurred earlier during the period of sexual initiation. Applying the feed restriction at the beginning (RP2) or at the end of the waiting phase (RP3) gave the same result. 
Aherne et al (1976), Friend et al (1981) and King (1989) also observed a retardation in puberty when feed restriction was imposed during the last 2 months preceding puberty with feed intake varying between 60 and $80 \%$ of the ad libitum level. Contrary to our results, Etienne et al (1983) showed that puberty is delayed when feed restriction is applied between 28 and $61 \mathrm{~kg}$ live weight. However, differences between the 2 studies can explain this discrepancy :

- feed restriction was applied until 149 days of age for our RP1 gilts instead of 169 days in the experiment of Etienne et al (1983);

- undernutrition was less severe in our experiment than in the previous one (feed intake: 1.41 vs $1.27 \mathrm{~kg} /$ days, average daily gain: 477 vs 393 g/day).

Our results suggest that a direct effect of undernutrition on sexual development exists, since the percentage of cyclic gilts at 230 days of age depended on the time of feed restriction while live weight was not modified and variations in fat thickness did not follow the same pattern. This influence of undernutrition can be explained by alterations in the secretion of neuropeptides and/or of various hormones which is known to be influenced by nutrient supply (insulin, growth hormone, cortisol, thyroxine). These endocrine alterations are likely to modify gonadotropin secretion by the pituitary or to act directly on follicular development at the ovarian level (Britt et al, 1988; Booth, 1990).

This experiment confirms that feed restriction can delay the attainment of puberty and shows that this effect depends on the time of application of the feed restriction: the last phase of the sexual development of the gilt (waiting phase) seems more sensitive. Moreover, it provides evidence that nutritional modulation of the re- productive function can occur independently of changes in body weight or composition. The endocrine bases of this phenomenon need further investigation.

\section{ACKNOWLEDGMENTS}

I gratefully acknowledge the technical assistance of B Carissant, G Conseil, F Giovanni, F Legouevec, $M$ Lemarie and AM Mounier. 1 also wish to thank JY Dourmad, M Etienne and $B$ Sèves for critical evaluation of the manuscript.

\section{REFERENCES}

Agde K, Schneider D, Buckhardt J (1978) Wachstumintensität der Ferkel und ihr Einfluss auf die Mast- und Schlachtleistungsmerkmale. Züchtungskunde 50, 3-16

Aherne FX, Christopherson RJ, Thompson JR, Hardin RT (1976) Factors affecting the onset of puberty, post weaning estrus and blood hormone levels of Lacombe gilts. Can J Anim Sci 56, 681-692

Booth PJ (1990) Metabolic influences on hypothalamic-pituitary-ovarian function in the pig. In: Control of Pig Reproduction III (DJA Cole, GR Foxcroft, BJ Weir, eds) Dorset Press, 89100

Britt JH, Armstrong JD, Cox NM (1988) Metabolic interfaces between nutrition and reproduction in pigs. Proc 11th Congr Anim Reprod Al, Dublin, 5, 117-125

Camous S, Prunier A, Pelletier J (1985) Plasma prolactin, $\mathrm{LH}, \mathrm{FSH}$, and estrogen excretion patterns in gilts during sexual development. $J$ Anim Sci 60, 1308-1317

Den Hartog LA, Noordewier GJ (1984) The effect of energy intake on age at puberty in gilts. J Agric Sci 32, 263-280

Desmoulin B, Ecolan P, Peiniau P, Melani C (1984) La classification des carcasses de porcs selon la teneur en viandes maigres : possibilité et limites de l'appareil Fat-OMeat'er danois. Journées Rech Porc France $16,37-48$ 
Etienne M, Camous S, Cuvillier A (1983) Effects de restrictions alimentaires pendant la croissance des truies sur leur maturité sexuelle et leur reproduction ultérieure. Reprod Nutr Dev 23, 309-319

Friend DW, Lodge GA, Elliot Jl (1981) Effects of energy and dry matter intake on age, body weight and backfat at puberty and on embryo mortality in gilts. J Anim Sci 53, 118-124

King RH (1989) A note on the effects of nutrient intake during the later stages of rearing and early reproductive life on the subsequent reproductive efficiency of gilts. Anim Prod 48, 241-244

Kirchgessner M, Dammert S, Giessler H (1979) Kompensatorisches Wachstum bei stark reduzierter Ernärungsintensität von Ferklen während der Aufzucht bis $30 \mathrm{~kg}$ lebendmasse. Züchtungskunde 51, 96-102

Kirkwood RN, Aherne FX (1985) Energy intake, body composition and reproductive perfor- mance of the maiden gilt. $J$ Anim Sci 60 , 1518-1529

Metz SHM, Gergstrom PL, Lenis NP, De Wys M, Dekker RA (1980) The effect of daily energy intake on growth rate and composition of weight gain in pigs. Livest Prod Sci 7, 79-87

Nelson RE, Robison OW (1976) Effects of postnatal maternal environment on reproduction of gilts. J Anim Sci 43, 71-77

Prunier A, Bonneau M, Etienne M (1987) Effects of age and live weight on the sexual development of gilts and boars fed two planes of nutrition. Reprod Nutr Dev 27, 689-700

Statistical Analysis Systems Institute, Inc (1985) SAS/STAT Guide for Personal Computers, Version 6. Cary, NC, USA, $378 \mathrm{pp}$

Terqui $M$, Thimonier J (1974) Nouvelle méthode radioimmunologique rapide pour l'estimation du niveau de progestérone plasmatique. Application pour le diagnostic précoce de gestation. CR Acad Sci (Paris) 29, 1109-1112 